\title{
Arterial Wall Metabolism and Atherosclerosis
}

\section{血管平滑筋カルシウムシグナリングの分子制御*}

田中利男** 日高弘義***

血管壁細胞におけるカルシウムシグナリングは, 動脈硬化症の発症や進展に重要な役割を果たして いるとされている，しかしながら，そのカルシウ ム作用の分子機序については不明な点が多く残さ れている.そこで，このシステムに対する独自の 選択的阻害剂を使用した分子薬理学的解析を試み たので報告する。

血管平滑筋収縮反応におけるカルシウム情報伝 達機構として, 近年カルシウム, カルモデュリン 依存性ミオシン軽鎖リン酸化反応が注目されてい る. すなわち, 細胞内カルシウムイオン濃度が上 昇するとカルモデュリンに結合するが，このカル シウムーカルモデュリン複合体はミオシン軽鎖リ ン酸酵素を活性化する. その結果リン酸化された ミオシンはアクチンとの相互作用が上昇するとさ れている.しかしながら，このミオシン軽鎖リン
酸化反応の平滑筋収縮反応における生理的意義は 明らかではない，そこでわれわれは，カルモデュ リン阻害剂 W-7, ミオシン軽鎖リン酸化酵素阻害 剤 ML-9 の分子レベルおよび組織レベルでの作用
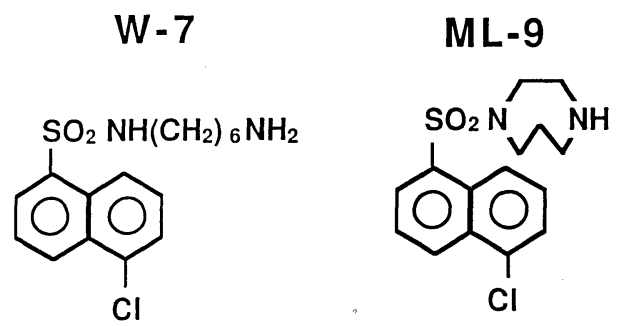

Fig. 1 カルモデュリン阻害剂 N-(6-aminohexyl)-5chloro-1-naphthalenesulfonamide (W-7) とミオ シン軽鎖リン酸化酵素阻害剂 1-(5-chloronaphthalenesulfonyl) - $1 \mathrm{H}$ - hexahydro-1,4 diazepine (ML-9) の化学構造.

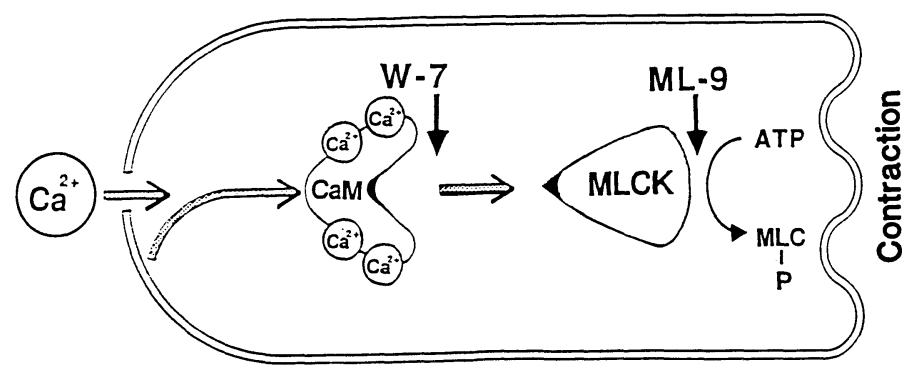

Fig. 2 血管平滑筋におけるカルシウム, カルモデュリン依存性ミオシン軽鎖リン酸化反応 の選択的阻害剂とその作用点.

CaM, カルモデュリン; MLCK, ミオシン軽鎖リン酸化酵素；MLC，ミオシン軽鎖

*1987 年 12 月, 日本動脈硬化学会 昭和 62 年度冬 季大会において発表

** 三重大学医学部薬理学教室

*** 名古屋大学医学部薬理学教室 
動脈硬化 Vol. 17 No. 11989

を比較検討した. W-7 はカルモデュリンにカル シウム依存性に結合することによりその生物活性 を抑制し，その結果，ミオシン軽鎖リン酸化反応， アクチン活性化ミオシンATPase および血管平滑 筋収縮反応を阻害することが明らかとなった。し かしながら，カルモデュリンは数多くの酵素系を 活性化することが知られており，ミオシン軽鎖リ ン酸化反応の生理的役割をW-7 だけで示すこと
は困難である.一方，ML-9 は，ミオシン軽鎖リ ン酸化酵素に直接作用する選択的阻害剂であり， 他のカルモデュリンの依存性酵素に対しては比較 的弱い作用しか認められなかった. さらに ML-9 は，種々のアゴニストによる血管収縮反応に対し て同様の抑制作用を示し，カルシウム，カルモデ ユリン依存性ミオシン軽鎖リン酸化反応の生理学 的重要性が強く示唆された。 